\title{
Use of Activated Charcoal in a Solid-Phase Extraction Technique for Analysis of Pesticide Residues in Tomatoes
}

\author{
Beatriz I. A. Kaipper ${ }^{a}$, Luiz A. S. Madureira ${ }^{a *}$ and Henry X. Corseuil ${ }^{b}$ \\ ${ }^{a}$ Departamento de Química, Universidade Federal de Santa Catarina, 88040-900, Florianópolis - SC, Brazil \\ bepartamento de Engenharia Sanitária, Universidade Federal de Santa Catarina, 88010-970, Florianópolis - SC, Brazil
}

\begin{abstract}
No presente trabalho foram desenvolvidos métodos de extração e purificação a fim de determinar e monitorar as concentrações dos pesticidas organofosforados mais utilizados em tomates na grande Florianópolis. A técnica de EFS com carvão ativo foi utilizada para a purificação e recuperação dos pesticidas metamidofós, acefato, malation e paration metílico. Os solventes para a extração e eluição foram escolhidos após diversas análises, sendo que os melhores resultados foram alcançados através da extração dos pesticidas com acetato de etila e eluição com $\mathrm{CH}_{2} \mathrm{Cl}_{2}$ - acetato de etila (7:3). A média recuperada dos analitos das matrizes fortificadas com $0,20-0,60 \mu \mathrm{g} \mathrm{g}^{-1}$ variou entre 85,2 e $100 \%$, com coeficientes de variação entre 1,3 e $6,3 \%$. Os limites de detecção foram de 0,04 a $0,12 \mathrm{ng} \mathrm{g}^{-1}$. $\mathrm{O}$ adsorvente carvão ativo mostrou-se eficiente para a purificação da matriz de tomate e para a recuperação quantitativa dos analitos, especialmente os mais polares.
\end{abstract}

The present work describes extraction and purification methods that were developed to determine and to monitor the content of organophosphorus pesticides in tomato crops from the agricultural district of Florianópolis, Brazil. SPE technique with activated charcoal was used for purification and recovery of the pesticides methamidophos, acephate, malation and methyl parathion. The solvents used for sample extraction and elution were chosen after several comparative tests. Best results were achieved using ethyl acetate for extraction and dichloromethane - ethyl acetate (7:3) for elution. Average recoveries from the matrices fortified with 0.20 to $0.60 \mu \mathrm{g} \mathrm{g}^{-1}$ ranged from 85.2 to $100 \%$ with overall coefficients of variation of 1.3 to $6.3 \%$. The limits of detection of the method varied between 0.04 and $0.12 \mathrm{ng} \mathrm{g}^{-1}$. Activated charcoal demonstrated to be efficient for tomato matrix purification and for quantitative recovery of the analytes.

Keywords: SPE/GC, organophosphorus pesticides, tomato

\section{Introduction}

After the banning of organochlorinate pesticides due to their high persistence in the environment, organophosphorus pesticides (OPPs), which have higher degradation rates, are currently the most employed in agriculture against several types of pests. Nevertheless, OPPs are characterized by their higher toxicity, which inhibits the enzyme acetylcholinesterase (an important neurotransmitter), and for remaining in food products due to their indiscriminate application by farmers ${ }^{1-4}$.

This work describes extraction and purification methods developed to determine four OPPs (methamidophos, acephate, malation and methyl parathion) in tomatoes. Three of those pesticides, methamidophos, acephate and methyl parathion,

\footnotetext{
* e-mail: madureira@qmc.ufsc.br
}

are applied in tomato cultivation in the area of the Cubatão-Sul basin, in the Florianópolis region, State of Santa Catarina, Brazil. In this area, which comprises the districts of Santo Amaro da Imperatriz, Águas Mornas and part of São José and Palhoça, tomato growing takes up about 620 ha and farmers use an annual pesticide average of $46.5 \mathrm{~kg}$ per hectare, which means an annual application of 30 tons of pesticides just in the tomato fields. This is the largest tomato producing area of the State, in which highly toxic OPPs (e.g., methamidophos, acephate and methyl parathion) are being used ${ }^{5}$.

The analytical methods to analyze pesticide residues in fruits and vegetables generally consist of the extraction of the analyte from the sample matrix, purification for removal of the undesired co-extractives and/or pre-concentration of analytes, and finally the instrumental analysis. Each analytical procedure is chosen according to the pesticide's chemical structure and the nature of the matrix ${ }^{6}$. 
Recently, techniques to analyze pesticide residues in fruits and vegetables have evolved significantly in terms of simplification, minimization and improvement of sample extraction and purification. Techniques such as Solid Phase Extraction (SPE) or Purification in Solid Phase (PSP), with procedures available in mini-columns ready for analysis, have made possible a minimization of the purification scale. An aliquot of the extract is purified and taken for analysis after the extraction of the analyte from the matrix. That sample minimization scale not only reduces the amount of solvent needed but also the time of analysis. The minimum scale used depends on factors such as the properties of the matrix, the homogenization step and the instrument's detection sensitivity ${ }^{6-9}$.

Given the frequently complex nature of the matrices, the analysis of OPPs in foods usually presents some specific difficulties. Solid particles and soluble constituents, like pigments, need to be removed from the extract, since they can lead to the deterioration of the capillary columns when determining analytes by gas chromatography. Due to a deposit on the bead, these solid particles can also cause a progressive reduction in the sensitivity of the nitrogenphosphorus detector (NPD) to analytes. Therefore, an efficient matrix purification for removal of undesired coextractives is required.

In this work, recovery studies of the OPPs malation, methamidophos, methyl parathion and acephate were performed in order to test the efficiency of the SPE method, including the use of sorbent activated charcoal and different solvents for extraction and elution. The fortification levels were selected at values close to the Maximum Residue Level (MRL) and quantification limits for the analytes. These values were based on practical laboratory experiments in which the smallest analyte concentration was verified with accuracy ${ }^{10}$.

Sorbent activated charcoal is widely used for plant extract purification as well as for other matrices, especially for the recovery of more polar OPPs, like methamidophos and acephate ${ }^{11-17}$. On the other hand, experiments carried out by Kaipper ${ }^{18}$ with the sorbents Florisil and $\mathrm{C}_{18}$, using the techniques of Matrix Dispersion of Solid Phase (MDSP) and Solid Phase Extraction (SPE), showed low recovery efficiency for methamidophos and acephate.

\section{Experimental}

\section{Samples and reagents}

Tomato samples were acquired in the organic food department at a local supermarket. The analyses of those samples confirmed the absence of the four OPP compounds discussed in the present study.
Merck 2186 activated charcoal was purified as follows: $10 \mathrm{~g}$ of activated charcoal was treated with $100 \mathrm{~mL}$ of $\mathrm{HCl}$ $3 \mathrm{~mol} \mathrm{~L}-1$, and heated at $40^{\circ} \mathrm{C}$ for $5 \mathrm{~min}$. The solution was filtered, and the treatment with $\mathrm{HCl}$ was repeated twice. Finally, the activated charcoal was washed with ultra-pure water ${ }^{17,19}$. Before using the purified activated charcoal, it was washed with $20 \mathrm{~mL}$ of ethyl acetate in a vacuum system (Millipore membrane $0.45 \mu \mathrm{m}, 47 \mathrm{~mm}$ diameter) and oven dried at $130{ }^{\circ} \mathrm{C}$ for $48 \mathrm{~h}^{13}$. During the filtering process, small particles of the activated charcoal were removed.

Standards of methamidophos (99\% purity), acephate (98\% purity), methyl parathion (99\% purity) and malation (99\% purity) were purchased from Hellma Sulamericana Importação e Exportação Ltda (São Paulo, SP, Brazil). The following Mallinckrodt solvent pesticide grades were purchased from Sigma-Aldrich Chemical Representações Ltda (São Paulo, SP, Brazil): acetone, dichloromethane, and ethyl acetate. The glass wool - supplied by Synth, Labsynth Products for laboratories (Deerfield, IL, USA) - was ultrasonicated three times with $\mathrm{CH}_{2} \mathrm{Cl}_{2}$ for 15 min before use. The solid phase extraction was performed using a Manifold system with cartridges supplied by Waters coupled to a vacuum pump.

\section{Extraction procedure}

Approximately $200 \mathrm{~g}$ of tomatoes were diced and processed in a blender at high speed for about $10 \mathrm{~min}$ to obtain an homogeneous pulp. Due to the pulp's high content of water there was no need to add an extra volume of water to it.

After homogenization, $5 \mathrm{~g}$ of sample was fortified with $75 \mu \mathrm{L}$ of standard solution of acephate $40 \mu \mathrm{g} \mathrm{mL}^{-1}, 100 \mu \mathrm{L}$ of standard solution of methamidophos $20 \mu \mathrm{g} \mathrm{mL}^{-1}, 100 \mu \mathrm{L}$ of methyl parathion and $100 \mu \mathrm{L}$ malation, the latter two standards with concentration of $10 \mu \mathrm{g} \mathrm{mL}^{-1}$. The sample was then ultrasonicated with $20 \mathrm{~mL}$ of ethyl acetate for 8 min. The extract was vacuum-filtered in a cellulose acetate membrane $(0.45 \mu \mathrm{m}, 47 \mathrm{~mm}$ diameter $)$ and concentrated to approximately $2 \mathrm{~mL}$ by rotary evaporation.

\section{Purification and pre-concentration in activated charcoal}

Mini-columns were prepared with a wad of glass wool at the bottom, a layer of $5 \mathrm{~mm}$ of anhydrous $\mathrm{Na}_{2} \mathrm{SO}_{4}$ and $200 \mathrm{mg}$ of activated charcoal. A layer of anhydrous $\mathrm{Na}_{2} \mathrm{SO}_{4}$ was also placed at the top of the column to avoid the sorbent becoming segregated. The activated charcoal had been previously treated following the procedure described above.

The concentrated tomato extract was transferred to the mini-column of activated charcoal, previously conditioned with $10 \mathrm{~mL}$ of ethyl acetate. The four OPP components were simultaneously eluted with $5 \mathrm{~mL}$ of ethyl acetate, at a $3 \mathrm{~mL} \mathrm{~min}^{-1}$ flow rate (Table 1 ). 
Table 1. Recoveries of OPPs by SPE using sorbent activated charcoal, extraction and elution with ethyl acetate.

\begin{tabular}{|c|c|c|c|c|c|}
\hline \multirow[t]{2}{*}{ Pesticides } & \multirow{2}{*}{$\begin{array}{c}\text { Fortification } \\
\text { level } \\
\left(\mu \mathrm{g} \mathrm{g}^{-1}\right)\end{array}$} & \multicolumn{2}{|c|}{$\begin{array}{c}\text { Elution with } \\
5 \mathrm{~mL}\end{array}$} & \multicolumn{2}{|c|}{$\begin{array}{c}\text { Elution with } \\
10 \mathrm{~mL}\end{array}$} \\
\hline & & Recovery (\%) & $\mathrm{CV}^{\mathrm{a}}(\%)$ & Recovery (\%) & $\mathrm{CV}(\%)$ \\
\hline Methamidophos & 0.40 & 91.4 & 9.9 & 99.5 & 5.0 \\
\hline Acephate & 0.60 & 34.1 & 11.5 & 99.0 & 2.5 \\
\hline Malathion & 0.20 & 31.3 & 4.8 & 71.7 & 0.4 \\
\hline Methyl parathion & 0.20 & - & - & - & - \\
\hline
\end{tabular}

${ }^{\mathrm{a} C o e f f i c i e n t s ~ o f ~ v a r i a t i o n ~ f o r ~ t h r e e ~ r e p l i c a t e s ~}$

The eluate was concentrated to approximately $2 \mathrm{~mL}$ in the rotatory evaporator at $40^{\circ} \mathrm{C}$, and then evaporated just to dryness with a low nitrogen flow. Finally, the dry extract was dissolved in $1 \mathrm{~mL}$ of acetone and analyzed by GC.

New experiments were carried out under the previous conditions but with different solvents for extraction and elution, as illustrated in Tables 2 and 3.

Table 2. Recoveries of OPPs by SPE using sorbent activated charcoal, extraction with acetone and elution with $10 \mathrm{~mL}$ of $\mathrm{CH}_{2} \mathrm{Cl}_{2}$ - acetone (7:3).

\begin{tabular}{lccc}
\hline Pesticides & $\begin{array}{c}\text { Fortification } \\
\text { level }\left(\mu \mathrm{g} \mathrm{g}^{-1}\right)\end{array}$ & Recovery $(\%)$ & $\mathrm{CV}^{\mathrm{a}}(\%)$ \\
\hline Methamidophos & 0.40 & 93.4 & 4.0 \\
Acephate & 0.60 & 70.4 & 10.4 \\
Malathion & 0.20 & 83.0 & 6.2 \\
Methyl parathion & 0.20 & 52.2 & 9.8 \\
\hline
\end{tabular}

${ }^{\mathrm{a} C o e f f i c i e n t s ~ o f ~ v a r i a t i o n ~ f o r ~ t h r e e ~ r e p l i c a t e s ~}$

\section{Chromatographic conditions}

Analyses were carried out in a gas chromatograph, Hewlett Packard 6890 model, fitted with a NP detector and an HP A 03.34 computerized integrator. Temperatures: capillary injection port $210^{\circ} \mathrm{C}$, detector $300^{\circ} \mathrm{C}$. Injection mode: manual $(1 \mu \mathrm{L})$ splitless (inlet purge on for 0.75 min) with a split flow 1:40. The column was an HP-5 capillary column (5\% diphenyl and 95\% dimethylpolysiloxane) of $30 \mathrm{~m} \times 0.25 \mathrm{~mm}$ id and $0.25 \mu \mathrm{m}$ film thickness, with the following oven temperature program: initial $40^{\circ} \mathrm{C}$, ramp rate $20^{\circ} \mathrm{C} \mathrm{min}^{-1}$, final $220^{\circ} \mathrm{C}$ at $5 \mathrm{~min}$. Gas flow: carrier (hydrogen), $3 \mathrm{~mL} \mathrm{~min}{ }^{-1}$; detector (hydrogen), $3 \mathrm{~mL} \mathrm{~min}^{-1}$; air, $60 \mathrm{~mL} \mathrm{~min}^{-1}$; and make-up (nitrogen), $10 \mathrm{~mL} \mathrm{~min}^{-1}$.

\section{Results and Discussion}

For elution, $5 \mathrm{~mL}$ of solvent was used at first. However, due to the low recovery levels obtained $(<35 \%)$, this volume was found to be insufficient (Table 1). The only exception was methamidophos, which showed an excellent recovery $(91.4 \%)$. This high value might be due to a lower activity (adsorption force) of the activated charcoal in relation to this OPP.

Using a larger volume of solvent for elution, an increase in the recovery of analytes was obtained with a small coefficient of variation (CV) for the extractions made (Table 1). However, in those conditions the methyl parathion was not recovered. It was also observed that the recovery of malation was not as good as that of the other two compounds. This result indicates that the activated charcoal's activity is higher for the less polar compounds: malation and methyl parathion. It was observed, however, that changing the solvent used for extraction and the solvent elution force improved the recovery of both methyl parathion and malation (Table 2). With this procedure using a gradient of acetone, a smaller recovery was observed for the analytes methamidophos and acephate as well as a larger $\mathrm{CV}$ for the acephate, when compared to the elution with ethyl acetate (Table 1).

To produce an increase in the solvent force, the mixture $\mathrm{CH}_{2} \mathrm{Cl}_{2}$ - ethyl acetate (7:3) was used as eluate, which resulted in an improvement in the recovery of all analytes, especially of methyl parathion, although it still showed low recovery (Table 3). The low values of CVs for the four analytes indicated that this method is the most accurate.

The estimation of the limit of detection (LOD) was based on the results obtained from the elution procedure

Table 3. Recoveries of OPPs by SPE using sorbent activated charcoal, extraction with ethyl acetate and elution with $10 \mathrm{~mL}$ of $\mathrm{CH}_{2} \mathrm{Cl}_{2}$ - ethyl acetate (7:3).

\begin{tabular}{|c|c|c|c|c|c|}
\hline Pesticides & $\begin{array}{c}\text { Fortification } \\
\text { level } \\
\left(\mu \mathrm{g} \mathrm{g}^{-1}\right)\end{array}$ & $\begin{array}{c}\text { Recovery } \\
(\%)\end{array}$ & $\begin{array}{l}\mathrm{CV}^{\mathrm{a}} \\
(\%)\end{array}$ & $\begin{array}{c}\mathrm{LOD}^{\mathrm{b}} \\
\left(\mathrm{ng} \mathrm{g}^{-1}\right)\end{array}$ & $\begin{array}{c}\mathrm{MRL}^{\mathrm{c}} \\
\left(\mu \mathrm{g} \mathrm{g}^{-1}\right)\end{array}$ \\
\hline Methamidophos & 0.40 & 99.0 & 4.2 & 0.04 & 0.30 \\
\hline Acephate & 0.60 & 97.2 & 1.3 & 0.12 & 0.50 \\
\hline Malathion & 0.20 & 100.0 & 0.8 & 0.07 & 3.00 \\
\hline Methyl parathion & 0.20 & 85.2 & 6.3 & 0.10 & 0.50 \\
\hline
\end{tabular}

${ }^{\mathrm{a}}$ Coefficients of variation for three replicates; ${ }^{\mathrm{b}}$ Limit of Detection; ${ }^{\mathrm{c}}$ Maximum Residue Level, Brazil - Ministry of Health ${ }^{20}$ 
with $\mathrm{CH}_{2} \mathrm{Cl}_{2}$ - ethyl acetate (7:3). In general, LOD is defined as the minimum concentration of an analyte necessary to produce a peak with a 3:1 signal-to-noise ratio $^{4,15,21}$. The low LOD values indicated that samples with much lower concentrations allowed by the Maximum Residue Limits (MRL) can also be analysed (Table 3).

The linear dynamic response range of the detector for each studied analyte (except malathion) was verified at intervals from 0.03 to $1.00 \mu \mathrm{g} \mathrm{g}^{-1}$ for methamidophos and from 0.05 to $1.00 \mu \mathrm{g} \mathrm{g}^{-1}$ for acephate and methyl parathion. The correlation coefficients were of $0.996,0.997$ and 0.998 for methamidophos, acephate and methyl parathion, respectively, showing good linearity for the method. The extraction efficiency was estimated at the fortification intervals, where a clear increase in the recovery levels was observed with increasing concentrations (Figure 1). The only exception was methyl parathion, which for a larger sample fortification showed a slight decrease in recovery (3\%), possibly due to an increase in the activity of the activated charcoal toward the less polar pesticide.

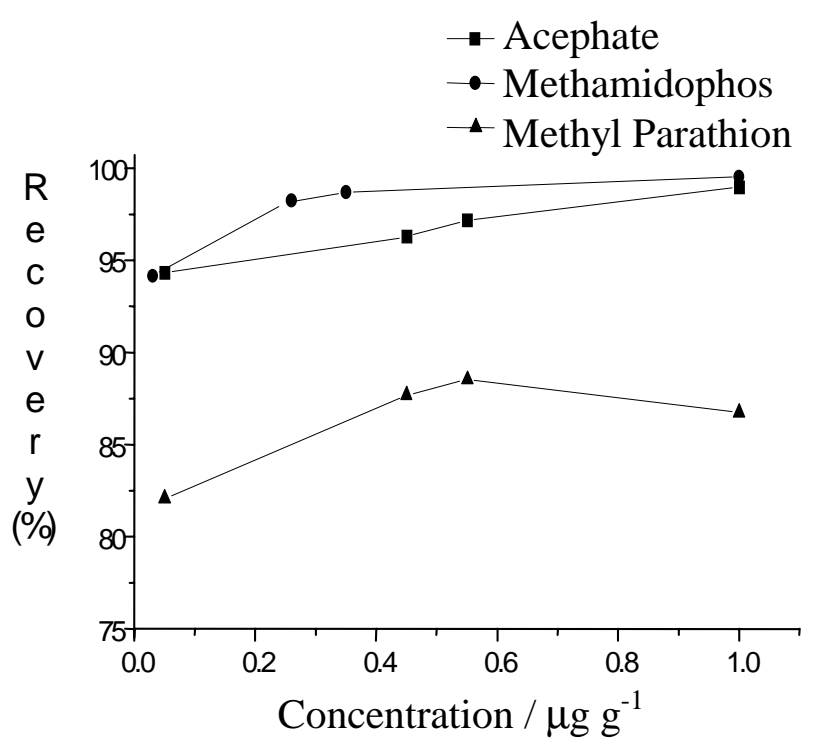

Figure 1. Extraction efficiency $v s$ concentration of samples fortified at the intervals of $0.03-1.00 \mu \mathrm{g} \mathrm{g}^{-1}$ for methamidophos and $0.05-1.00 \mu \mathrm{g} \mathrm{g}^{-1}$ for acephate and methyl parathion, using SPE with activated charcoal. Extraction with ethyl acetate and elution with $\mathrm{CH}_{2} \mathrm{Cl}_{2}$ - ethyl acetate (7:3). Each point corresponds to the average of three injections with experiments performed in duplicate.

In spite of the complexity of the sample, which contained several undesired compounds, the recovery of analytes was higher than $85 \%$. The activated charcoal retained the pigments, showing an excellent capacity for purification in all recovery tests made (Figure 2). With the use of activated charcoal, impurities found in the tests with $\mathrm{C}_{18}$ and Florisil were not observed ${ }^{18}$. This means that the sorbent chosen was very selective for the tomato pigments and allowed the recovery of the four OPPs despite their different structural characteristics. It is worth mentioning that the sensitivity of the method could be improved by using a lower final volume of the solution for analysis.

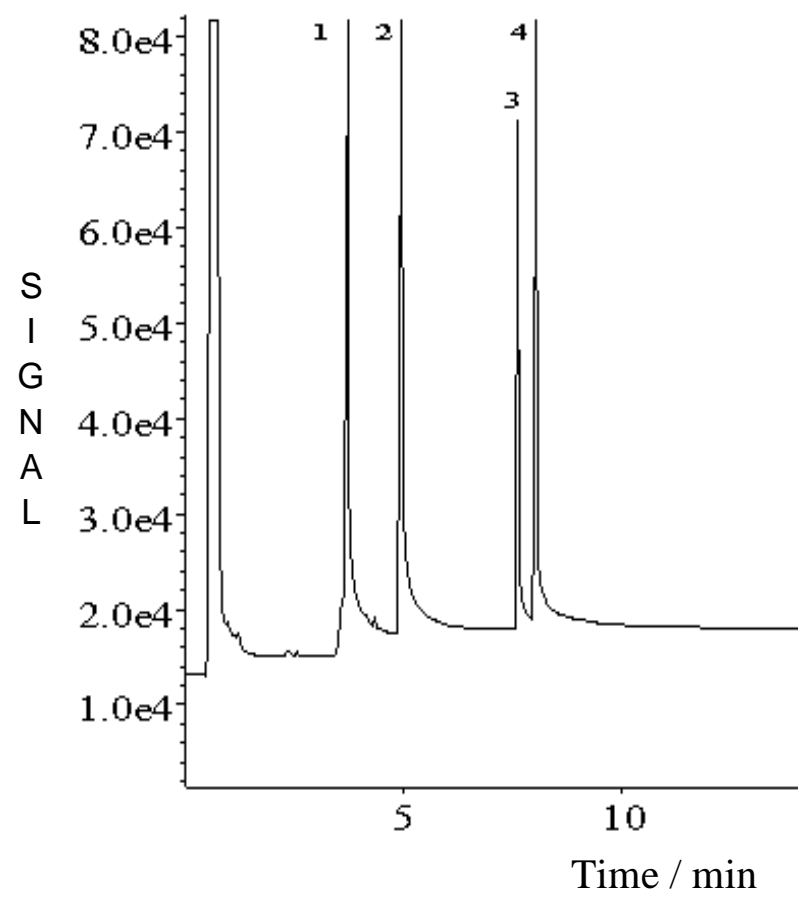

Figure 2. Chromatogram showing OPPs recoveries after purification by SPE using activated charcoal, extraction with ethyl acetate and elution with $\mathrm{CH}_{2} \mathrm{Cl}_{2}$ - ethyl acetate (7:3). The peaks correspond to the pesticides methamidophos (1), acephate (2), methyl parathion (3), and malathion (4).

The use of ethyl acetate for extraction proved to be a good choice. Excellent results have been achieved in comparison to several solvents used for extraction and elution in analyses of fruits and vegetables, as has been reported by several authors ${ }^{11-15,22,23}$.

Peak tailings were observed throughout the analyses for all OPPs (Figure 2). This seems to be a characteristic of organophosphorus compounds when analyzed by NPD. The tails obtained using ceramic pearls - which have a different reaction mechanism than the glass pearls previously used in $\mathrm{NPDs}^{24}$ - are in fact normal, especially those from the analysis of compounds containing nitrogen and phosphorus.

\section{Conclusions}

The results obtained in the present study show that activated charcoal is an efficient sorbent of pigments from the tomato matrix and that it improved the recovery of pesticides of different polarities. In addition, the SPE technique has shown advantages such as simplification in the extraction and purification steps, lower solvent consumption, and time of analysis. 


\section{Acknowledgements}

B. I. A. K. thanks CAPES for a MSc scholarship. We thank FUNPESQUISA for the financial support to carry on this work.

\section{References}

1. Lee, W. O.; Law, L. M.; Wong, S. K. Food Addit. Contam. 1996, 13, 687.

2. Dorea, H. S.; Barbirato, M. A.; Lanças, F. M. Pesticidas: R. Ecotoxicol. e Meio Ambiente 1997, 7, 109.

3. Nóvak, E. M.; Follador, F. R. Pesticidas R. Téc. Cient. 1992, 2, 37.

4. Magdic, S.; Boland-Boyd, A.; Jinmo, K.; Pawliszyn, J. B. J. Chromatogr., A 1996, 736, 219.

5. Projeto Tecnologias Ambientais para o Desenvolvimento Sustentável da Bacia do Cubatão - Departamento de Engenharia Sanitária e Ambiental - Universidade Federal de Santa Catarina ; Brasil, 1995.

6. Tekel, J.; Hatrík, S. J. Chromatogr., A 1996, 754, 397.

7. Torres, C. M.; Picó, Y; Mañes, J. J. Chromatogr., A 1996, 754, 301.

8. Wan, H. B.; Wong, M. K. J. Chromatogr., A 1996, 754,43 .

9. Di Muccio, A.; Dommarco, R.; Barbini, D. A.; Santilio, A.; Girolimetti, S.; Ausili, A.; Ventriglia, M.; Generali, T.; Vergoni, L. J. Chromatogr., A 1993, 643, 363.

10. Kadenczki, L.; Arpad, Z.; Gardi, I.; Ambrus, A.; Gyorfi, L.; Reese, G.; Ebing, W. JAOAC 1992, 75, 53.
11. Cai, C. P.; Liang, M.; Wen, R. R. Chromatographia 1995, 40, 417.

12. Dorea, H. S.; Tadeo, J. L.; Sanchez, C. S. Chromatographia 1996, 43, 380.

13. Szeto, S. Y.; Maccarthy, H. R.; Oloffs, P. C. J. Environ. Sci. Health, Part B 1979, B14, 635.

14. Szeto, S. Y.; Brown, M. J. J. Chromatogr., A 1982 , $240,526$.

15. Sundaram, K. M.; Nott, R. J. Chromatogr., A 1992 , 627,300 .

16. Lee, W. O.; Law, L. M.; Wong, S. K. Food Addit. Contam. 1996, 13, 687.

17. Morita, T. Assumpção, R. M. V. Manual de Soluções, Reagentes e Solventes, Edgard Blücher Ltda; Brasil, 1986, p 627.

18. Kaipper, B.I.A. MSc. Thesis, Universidade Federal de Santa Catarina, 1998.

19. Vanderborght, B. M.; Van Grieken, R. E. Anal. Chem. 1977, 49, 311.

20. Brazil - Ministry of Health; Relação de Substâncias para Uso Fitossanitário e Domissanitário; Portarias do Ministério da Saúde; São Paulo: ILSI, 1995, p 715 .

21. Agüera, A.; Contreras, M. J. Chromatogr., A 1993, 655, 293.

22. Holstege, D. M.; Scharberg, D. L.; Tor, E. R.; Hart, L. C.; Galey, F. D. JAOAC 1994, 77, 1263.

23. Steinwander, H. Fresenius'J. Anal. Chem. 1992, 343, 887.

24. HP 6890 Series Gas Chromatography, Operating Manual, Manual Part. N.G1530-90310, Brasil, 1995.

Received: July 21, 2000

Published on the web: July 05, 2001 